\title{
The Effects of Policies for Training and Skills on Improving Innovation Capabilities in Firms
}

Compendium of Evidence on the Effectiveness of Innovation Policy Intervention

Barbara Jones

and

Damian Grimshaw

Manchester Institute of Innovation Research Manchester Business School, University of Manchester http://research.mbs.ac.uk/innovation/ 
This report is part of the Compendium of Evidence on the Effectiveness of Innovation Policy Intervention Project led by the Manchester Institute of Innovation Research (MIoIR), University of Manchester. The project is funded by the National Endowment for Science, Technology and the Arts (NESTA) - an independent body with the mission to make the UK more innovative.

The compendium is organised around 20 innovation policy topics categorised primarily according to their policy objectives. Currently, some of these reports are available.

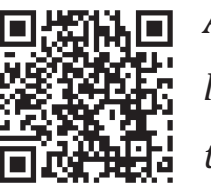

All reports are available at http://www.innovation-policy.org.uk. Also at this location is an online strategic intelligence tool with an extensive list of references that present evidence for the effectiveness of each particular innovation policy objective. Summaries and download links are provided for key references. These can also be reached by clicking in the references in this document. 


\section{Table of Contents}

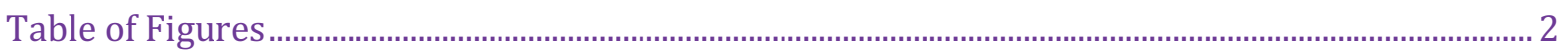

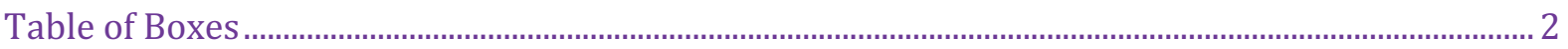

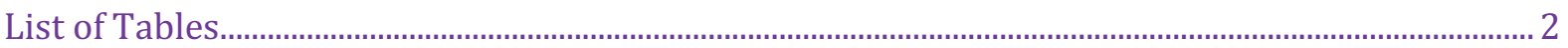

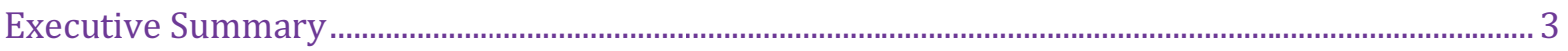

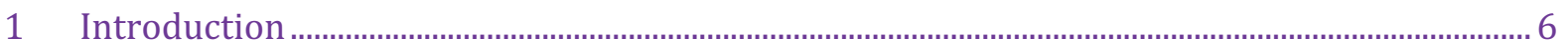

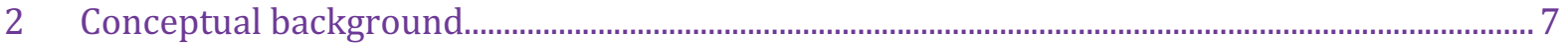

$2.1 \quad$ Starting point: limited conceptualisation..................................................................................... 7

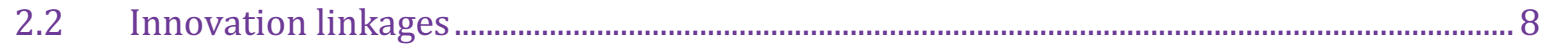

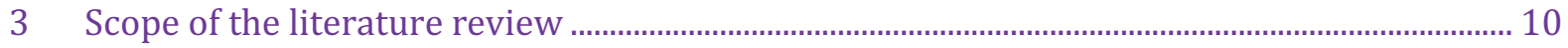

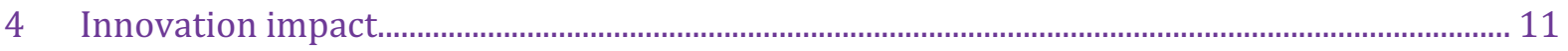

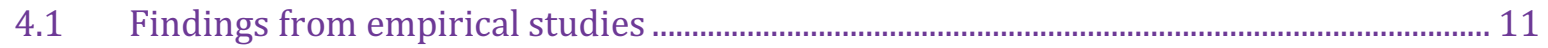

4.2 How to value and utilise skills for innovation success ............................................................ 13

4.3 The costs and financing of training at enterprise Level ............................................................ 14

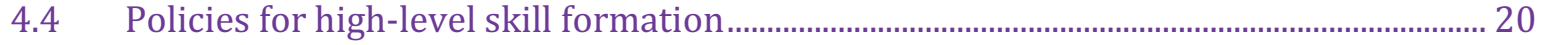

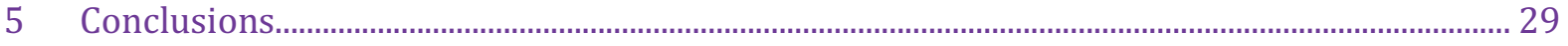

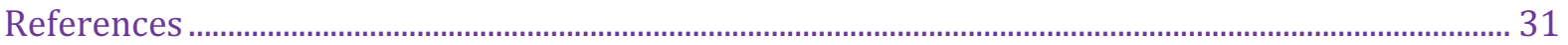

\section{Table of Figures}

Figure 1: A model of interlinkages between components of skill systems and innovation

\section{Table of Boxes}

Box 1: Country examples of direct reimbursement of training......

\section{List of Tables}

Table 1: Summary of evaluations of the contribution of training to improved performance ...... 12

Table 2: Levy schemes, policy lessons and country examples............................................................... 16

Table 3: Advantages and limitations of levy systems ............................................................................ 19

Table 4: Graduate and post graduate student-industry collaboration: summary of some

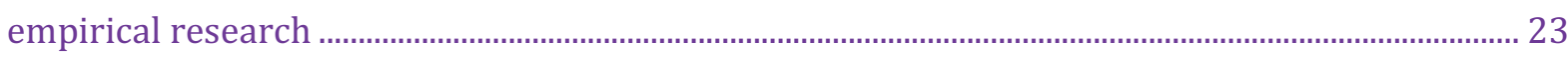

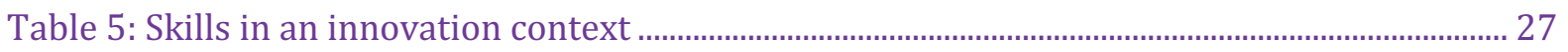




\section{Executive Summary}

Skills and innovation are often claimed to be the twin engines of economic growth but there is a surprisingly limited appreciation of how these core features combine and interact both at the firm level and at the interface between tertiary education and industry. Governments around the world, especially in high-income countries, have invested in training schemes and in higher education to improve 'human resources in science and technology', as well as to grow the pool of 'knowledge workers' equipped with skills of problem-solving and analytical thinking ready to contribute to expanding knowledge-intensive industries. There is thus an apparent consensus that skilled workers in both the public and private sectors are needed to create and diffuse the knowledge needed for successful innovation performance. But what evidence underpins this policy consensus? In particular:

- Do innovative firms tend to utilize a more skilled workforce than non-innovative firms?

- Do innovative firms devote more resources to training provision than non-innovative firms?

- What are the inter-linkages between skill types and innovation types and do these vary by industry (e.g. services versus manufacturing)?

- Are there benefits from new systems for valuing skills in the market place?

- How important are levy and other incentive schemes for enhancing the skill pool?

- What are the relative merits of high-level, tertiary education as opposed to intermediate, vocational training for innovation?

At the conceptual level, a cursory reading of the innovation literature reveals a rather oblique interest in matters of worker skill and workplace-based training. Notions of 'in-house capacity', 'knowhow' and 'human capabilities' are theorized in preference over more real-world notions such as on-the-job training, apprenticeships, graduate training and shared training programmes. This makes it difficult to draw out the inferences for training and skill from the conclusions of innovation research.

Nevertheless, this report distils four key analytical concepts from innovation studies and makes the relevant links with innovation performance at firm level. These are:

- knowledge (e.g. knowledge cumulativeness implies a need for sustained commitment to skill development for innovation);

- skill (e.g.. project skills are critical for radical innovations but we understand very little about how to organize these mixed tacit and formal skills);

- training (e.g. training expenditures are critical for technology diffusion and to support technology investments); and

- firm competences (e.g. competences play a key role in underpinning absorptive capacity).

While there are many useful insights in the literature, for the most part the training/skillinnovation inter-linkages remain under-researched. Most studies set out with the rather modest task of analyzing simple associations, for example between R\&D spending and the share of qualified scientists and engineers in the sector or firm. Where there is a focus on the effects of differences in training provision or skill-mix at the level of the firm the analysis tends to focus on the productivity and profitability effects rather than innovation. 
A state-of-the-art review of the limited empirical evidence on the association between training/skill and innovative performance at the firm level reveals two key findings:

1. There appears to be a positive association between innovative firms and the level of expenditures on formal and informal training compared to non-innovative firms; and

2. Firms benefit from a significant positive effect by developing their 'knowledge pool',particularly with respect to the organization's legacy of past innovations and the technical competences of owner-managers in small and medium-sized firms.

These findings have illuminated some issues and insights that have significance for innovation policy:

- high skill-mixes in firms need to be developed through better incentives;

- both tertiary level education and vocational training produce valuable skills - in particular there is a clear positive innovation effect of intermediate technical skills and a firm's investment in 'technicians';

- innovative performance is associated with the making rather than the buying of skills because of the way skill development enhances absorptive capacity; and

- the evidence of sector-specific inter-linkages between training and innovation supports the need to further reinforce institutions such as sector skill councils.

There are nevertheless gaps in our knowledge. We do not know much about what groups of workers and managers within an organisation need particular training for the skills required to enhance innovation performance. Also, surveys show that many skills are under-utilised by firms suggesting that workers do not often enjoy the opportunity to contribute to improving innovation performance. Moreover, many firms do not systematically calculate the costs or measure the benefits of training; Eurostat company surveys indicate that almost three in five companies do not evaluate the effects of their training provision.

The report reviews empirical evidence associated with two important areas of education and training policy - i) Levy schemes for enterprise training and ii) Policies for high-level skill formation:

\section{i) Levy schemes for enterprise training}

The report considers the relative merits of levy schemes for encouraging training as a potentially fruitful policy mechanism designed to facilitate and/or improve innovation performance. An international review of country experiences of levies, tax rebates and tax incentives draws out several lessons for policy.

First, compulsory systems have the advantage of an economy-wide approach but may require strong engagement of social partners to establish a lasting reputation. Second, the careful positioning of a levy scheme within the wider skill formation system of an economy is fundamental to its design since there may be a positive opportunity to develop the wider training infrastructure through new agencies in the public and private sectors. Third, schemes can be targeted, for example with special provisions for small and medium-sized firms or for sectors such as construction or social care. Finally, given the tendency for employers to favour skills tailored to the needs of their business some schemes are notable in that they usefully 
incorporate incentives to encourage the development of general, transferable skills. Further empirical research is urgently required in this important policy area.

\section{ii) Policies for high-level skill formation}

In the area of higher skills, a key preoccupation for policy-makers and practitioners is the extent to which tertiary education can effectively meet employers' demands, particularly in innovative sectors of the economy. University-industry collaborations and partnerships seek to address this policy challenge. They have existed for some while and continue to be developed as part of innovation policy strategies.

The significance of these types of schemes between employers and universities may be their recognition of the value of human resource formation in terms of skills, knowledge and expertise acquired in the workplace which can be validated at the tertiary level of education, whether through undergraduate and postgraduate degree programmes or business-related professional doctorates. It is, however, as yet unclear as to whether these sorts of schemes are sufficiently similar in their design and operation so as to facilitate lessons for cross-national policy transfer in order to improve policy interventions in different national contexts. Further research is needed to determine the value of these approaches as tools for policy interventions aimed at increasing innovative capacity through unique skill formation pathways and the validation of industrial expertise at postgraduate qualification level.

The report concludes with several recommendations for further research and investigation as well as for policy and practice. These include the following:

- in-depth interrogation of the innovation consequences of targeted sector-based training investments;

- finance and support cross-national evaluations of the innovation effects of varying training levy schemes;

- exploration of new processes and methods through which firms assign value to their stock of skills and commit to prospective training investments;

- further exploration of the innovation impacts of university-industry collaborations; and

- the development of new approaches to training in doctoral and post-doctoral studies. 


\section{Introduction}

The policy discourse about innovation has generally held that governments should facilitate the creation and transfers of knowledge and remove unnecessary impediments to its diffusion. Typically this means governments should subsidies the creation of new knowledge through publicly funded scientific research and support for higher education and better quality schooling, as well as the coordination and/or investment in vocational education and training. In many countries, therefore, governments have intervened with numerous innovation policy initiatives to expand the tertiary education sector and increase R\&D expenditures, including for example the recent policy focus on expanding 'Human Resources in Science and Technology' (HRST). This recent policy focus responds to the wider policy objective, common to most high income countries, of moving towards a knowledge-based innovative economy as the mechanism for successful competitive growth; in particular, it seeks to meet a rising demand for a particular bundle of skill and expertise that includes conceptual problem-solving and analytical reasoning (Brown et al. 2001, Gallie 2009).

Yet it also reflects a growing awareness over recent years that innovation combined with the development and accumulation of skills potentially act as the 'twin engines of growth' (LloydEllis and Roberts 2002), which can be guided by appropriate policy measures at the firm, regional and national levels ${ }^{1}$. A skilled workforce is a key conduit for the creation, transfer and diffusion of knowledge and provides a foundation for innovation to occur.

While investments in HRST and leading-edge scientific and engineering endeavours are undoubtedly critical for productivity and economic growth, policies with a narrow HRST focus are likely to generate deficits in the wider stock of essential technical and intermediate-level skill and knowledge (Bosch and Charest 2009, Steedman et al. 1991, Grubb 1996), which is typically developed through combinations of school and workplace-based vocational education and training. Careful consideration of the roles played by HRST and more general technical and intermediate skills in fostering and sustaining innovation is thus required in order to support an effective policy framework.

Nevertheless, the formulation of policy in a context of deep uncertainty and instability in economic prosperity, along with fast-changing technologies, a much-shortened product life cycle across multiple markets and intensified global competition, is a complex task. Recent decades have witnessed waves of obsolescence of skills as a result of wholesale replacements of technologies and their associated infrastructures. Moreover, in the context of the ongoing recession and austerity, firms and governments lack the incentives to invest in new skills because of uncertainty about both their ability to recoup the returns and whether or not the new skills will fit with new technological developments. The low-risk response is to invest in 'generic' or 'adaptable' skills often at the expense of under-investing in specialist scientific and technical skills and knowledge at both intermediate and high levels. The key issue here is that markets are not designed to send effective signals to the various actors (students, workers, employers and governments) to allocate the required funds for skill development. The problem of 'market failure' of education and training systems is widely recognized, as is the danger of

This approach is linked to the longstanding view in economics that skill is a driver for economic growth at the level of the firm (Becker 1964, Bowles et al. 2001). 
under-investment which can easily lead to a vicious downward spiral of deskilling, whereby capital investment adjusts its technological level to that of the low level of skills available, in turn creating more demand for lower level skills, which discourages further investment in higher level skills ( $\underline{\text { Snower 1996). }}$

A further issue is that training and patterns of learning occur in multiple forms. Formal and informal mechanisms of interaction and learning within firms enable employees to share information, challenge existing routines and practices, and experiment and collaborate to improve products and processes. The form of training provision and the wider skill formation system provide a set of limits and opportunities for guiding innovation performance at all levels of the economy. Training is thus defined by conditions internal and external to the firm including on the one hand the organisation-specific design of jobs and informal/formal training provision, as well as the human resource policies of recruitment, pay and careers that nurture a particular skill-set among the workforce, and, on the other hand, the external institutional forms of schooling, higher education and the roles of government, employers and unions in delivering vocational training (e.g. Keep and Mayhew 2010, Warhurst et al. 2004). Policy interventions aimed at innovative capacity in firms are presented with a number of challenges. Training and skills policies are usually part of a wider policy effort that seeks to improve economic growth and employment participation rather than being specifically designed and implemented with the goal of strengthening innovation capabilities at the firm or sector levels. Although the articulation of linkages between skills and innovation can be identified in principle, the mechanisms through which they interact in the real-world economy remain somewhat opaque.

This report reviews the key impacts of training policy on innovation performance. It begins by setting out the relevant conceptual background for understanding the interlinkages between components of skill systems and innovation. Section 3 describes the scope of the literature and policy review that is undertaken in section 4 considers the impact of policies in enhancing medium and high level skills through levy systems, new ways of valuing skills and through university industry collaborations: Section 5 concludes by drawing out the lessons for policy.

\section{Conceptual background}

\subsection{Starting point: limited conceptualisation}

Despite its obvious relevance for innovation and its role in enhancing competitiveness, the innovation literature has been remarkably laggard in appreciating the need for detailed interrogation of the character and meaning of skills formation and training systems (although see Lorenz and Lundvall 2006, Tether et al. 2005). Indeed, Edquist (2005) has argued relatively recently that,

'[there] is little systematic knowledge about the ways in which the organization of education and training influences the development, diffusion and use of innovations' (2005: 185).

Within the innovation and business studies literature (encompassing many different approaches to innovation) there is agreement that firms require people with particular bundles of skills to pursue different product-market strategies: employees with 'general' or 'multitasking' skills are said to be needed for radical product innovation (RPI), workers with 'firmspecific' or 'occupational specialization' skills are seen to facilitate incremental product innovation (IPI) and low qualified (inexpensive) labour is claimed to be required for low cost 
production based on product imitation (PI) (Porter 1990, Freeman and Soete 1997, Hall and Soskice 2001, Casper and Whitley 2004, Nooteboom et al. 2007, Patel and Pavitt 1994). Underpinning this model is the accepted notion that the increased exposure of people to new ideas - be it in the form of employees changing firms more regularly, be it in the form of scientists as autonomous and performance oriented in their choice of research projects - is crucial for the emergence of radical innovations.

What is not clear, however, is whether firms need to hire scientists, for example, with a particular knowledge profile in addition to a workforce with distinct qualifications or particular skill profiles in order to pursue RPI, IPI, and/or PI strategies of innovation, respectively. A focus on the specific types, qualities and compositions of such skills embedded in specific occupations and industries, along with attention to the changing nature and evolution of skills in the most innovative and technologically advanced areas of the economy, have both been absent from the main body of the innovation studies literature at considerable cost to our understanding of the interaction processes.

\subsection{Innovation linkages}

This next section briefly hypothesises the various interlinkages between the concepts of knowledge, skill, training and firm competencies and the resulting innovation. Figure 1 presents a stylised portrayal of the mechanisms bridging skill and training with innovation.

\section{Links between knowledge and innovation:}

- the degree of accessibility of knowledge is critical to innovation impacts. Greater accessibility of knowledge among firms within a given sector brings lower appropriability, since competitors gain knowledge and can imitate new products/processes for example (Malerba 2004);

- the degree of cumulativeness of knowledge impacts upon innovation. For example, a first- mover advantage enjoyed by a firm may generate a 'success breeds success' environment where the knowledge is highly cumulative (Malerba 2004). 
Figure 1: A model of interlinkages between components of skill systems and innovation

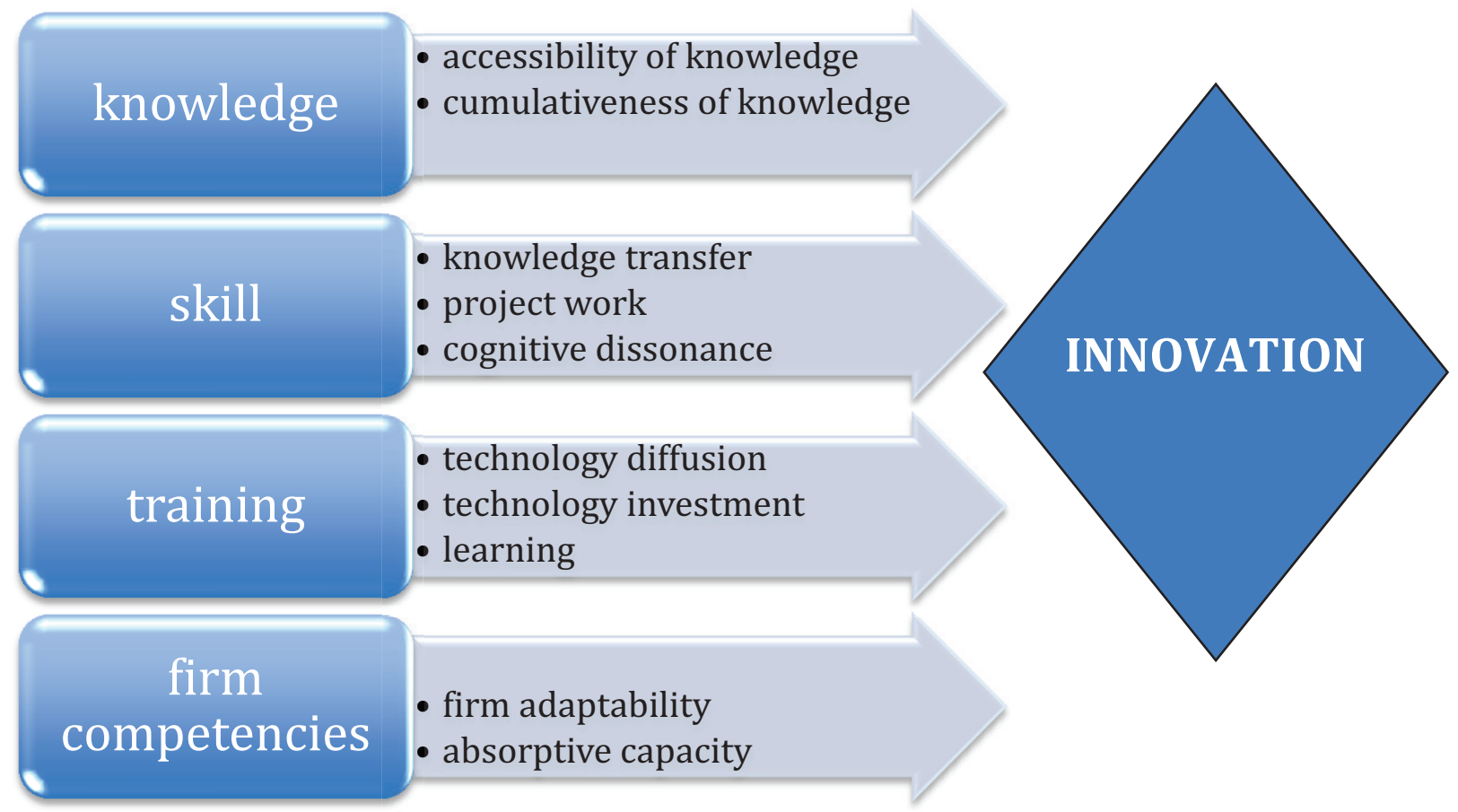

Linkages between skill and innovation

- Skilled workers can play a critical role in the transfer of knowledge between firms, sectors and countries, whether through collaboration on R\&D and technical problemsolving by firms involved in supply-chains (Lundvall 1992), mobility of highly-qualified engineers and scientists between firms (Mason et al. 2004) or in facilitating the acquisition of client-specific knowledge in complex models of outsourcing plus staff transfer (Miozzo and Grimshaw 2011);

- An increasing number of persons are employed in activities where skills are developed in and through innovative project work. The acceleration of the development of new skill-sets and technologies is combined with a tendency for developmental, design, and implementation work to be carried out by multi-disciplinary teams often working on specific projects (Whitley 2006). In these environments it is difficult to assign skills to individuals, since while working on problems individuals develop tacit or local knowledge of specific aspects of the work which do not necessarily belong within the area of their core competence. The design industry is illustrative. Recent studies suggest large design firms are organised 'around a multi-unit skill system to leverage economies of scope ... [reliant upon] a combination of professional knowledge bases and somewhat formalised processes to provide unique service offerings' (Miozzo et al. 2012: 156). The skills and knowledge within such firm units are also a function of spillovers from contact with workers in other firms which may be quite different from one locality or firm to another. Since many workers in such situations use computer software or other analytical tools which have a great potential for different uses they can develop different paths to innovative outcomes which may never be replicated by a team composed of persons with different knowledge and skills; 
- Fast-changing environments (related to product markets, work organisation, new technologies) can lead to problems of cognitive dissonance between employees and managers in relation to the definition of skills and training which can have adverse or unintended consequences for innovation. The problems are often represented as skill gaps or skill shortages, as well as failures in the understanding of how existing skills are being transformed in the innovation process. At the same time, problems of skill gaps can in certain circumstances be compatible with a successful innovative economy for the following reasoning. Successful innovation creates a demand for new levels of skills and skill-sets, which the education and training systems can only gradually meet because of the normal lags of policy response. As such, it would be unreasonable to expect an innovative economy to be one without shortages of skilled labour.

\section{Linkages between training and innovation}

- Training can be construed as a mechanism for technology diffusion where the effective deployment of technology and improved operational techniques invariably involve changes in human capital requirements. Linkage effects tend to be sector-specific since much depends on the level of technological investment and type of product market competition

- Forms of learning are shaped by distinctive and path-dependent conventions/traditions with respect to how to solve employment and innovation problems through single-firm approaches, sector initiatives, government-subsidised methods or coordinated actions among government and social partners (see Bosch and Charest 2009).

\section{Linkages between firm competencies and innovation}

- A key firm strategy is to exploit its competencies in order to 'build capacity', that is, the ability to develop and realise strategies to adapt to new circumstances. In order for firms to identify and make effective use of knowledge, ideas and technologies generated elsewhere, what is required is dynamic capability and absorptive capacity, which may be created through the development or acquisition of high levels of workforce skills (Teece et al. 1997, Teece and Pisano 1998, Griffith et al. 2004).

- Underlying and assisting the development of absorptive capacity is the ability and skills of the workforce that firms have to draw upon. The stock of skills inevitably sets limits on how much firms can develop this capacity. Increasing the stock of skills and distributing their deployment to where they are best operationalised within the value chain is then critical to achieving greater international competitiveness. ${ }^{2}$

\section{Scope of the literature review}

Our literature search was conducted on the Web of Science and databases of ERIC, CEDEFOP ILO, UNEVOC and OECD Studies in Innovation in order to cover a wide range of sources from the academic innovation literature, national policy documents and innovation policy reports.

Very few studies emerged that were specifically focused on demonstrating an empirical causal relationship between skill formation and innovation or on the impact of policies specifically targeted at training, skill formation and innovation; most were concerned with the effect of

\footnotetext{
${ }^{2}$ See, for example, Leitch Review of Skills (2006) for further evidence.
} 
training on productivity and/or profitability and on the work environment. This may be because data regarding on-the-job training and probably most in-company training schemes are underreported and fragmented (Nilsson 2010) making it difficult to assess the impact of firm training on innovation and the impact of policies aimed at enhancing skill formation for innovation.

It should be noted that a particular problem at a conceptual level is that the complex nature of training and skill development has been somewhat obscured by the application of Becker's simplified dualist categorisation of training as either general or firm-specific, which makes it difficult to extrapolate a real-world connection with innovation performance ( $\underline{\text { Smits 2008). }}$ ). Becker's (1964) categories suppose general training adds to the value of trained labour in any occupation and specific training is only of value to a specific employer. If this were true, it would be relatively easy to assign the cost of training to one partner or the other and the impact of training on productivity/profitability. The problem is that cases of pure general or pure specific training are rare: most training necessarily contains both general and specific elements. In different economic sectors the boundaries between general and specific are inherently different depending on the degree to which work processes can be varied: the degree of specificity varies and so does market valuation of the skills.

There is a wide literature relating to the area of university industry collaboration and partnerships but less so in the field of how universities actually affect the rate and direction of innovation processes through human resource skills training for graduates and postgraduates. Our findings in this regard are presented in section 4.4.

\section{Innovation impact}

\subsection{Findings from empirical studies}

Several studies have sought to investigate the impact of training and skill development on dimensions of economic performance, including in some cases innovation performance (summarised in table 1). Two international reviews provide a valuable starting point. These meta-analyses include a major OECD (1998) evaluation of 19 studies covering 10 countries and a more recent Cedefop report (Descy \& Tessaring 2005) that summarises 13 studies from eight countries.

Two outcomes from these meta-analyses are clear. First, firms that provide training enjoy productivity gains and these gains are approximately divided between the workforce (wage increases) and the firm (increases in productivity). Second, both reviews generally confirm that firm-based training has the greatest impact on performance when undertaken in connection with wider changes in work organisation, job structure, and, in some instances, technological innovation. Overall, it is striking that only four studies out of 32 reviewed in these two reports referred explicitly to innovation in the context of skills and training. The impact of training policies was primarily discussed in terms of its macroeconomic implications for job growth under conditions of skill shortages or mismatches. 
Table 1: Summary of evaluations of the contribution of training to improved performance

\begin{tabular}{|c|c|c|}
\hline Study & Evaluation Focus & Relevant Findings \\
\hline$\underline{\text { Abreu et al. (2010) }}$ & $\begin{array}{l}\text { The different training linkages } \\
\text { between services and } \\
\text { manufacturing firms }\end{array}$ & $\begin{array}{l}\text { Service firms in the UK tend to commit a higher share } \\
\text { than manufacturing of spending to training with an } \\
\text { explicit innovation component }\end{array}$ \\
\hline Amara et al. (2008) & $\begin{array}{l}\text { The investments in training } \\
\text { required for innovation }\end{array}$ & $\begin{array}{l}\text { - Firms require an adequate knowledge pool of } \\
\text { skilled employees to develop both incremental } \\
\text { and radical innovations } \\
\text { This pool of knowledge can be enhanced through } \\
\text { investments in staff training }\end{array}$ \\
\hline Baldwin and Johnson (1996) & $\begin{array}{l}\text { The features of training } \\
\text { provision in more/less } \\
\text { innovative firms }\end{array}$ & $\begin{array}{l}\text { More innovative firms offer formal and informal } \\
\text { training more often and with greater continuity than } \\
\text { less innovative firms }\end{array}$ \\
\hline $\begin{array}{l}\text { Danish Ministry of Business and } \\
\text { Industry (1996) }\end{array}$ & $\begin{array}{l}\text { Implications of technological } \\
\text { and organisational change for } \\
\text { labour demand, firm } \\
\text { performance and industrial } \\
\text { policy }\end{array}$ & $\begin{array}{l}\text { Firms that introduced process/product innovation } \\
\text { plus training were more likely than non innovators to } \\
\text { report output growth, job growth and labour } \\
\text { productivity growth }\end{array}$ \\
\hline Freel (2005) & $\begin{array}{l}\text { Association between firm level } \\
\text { innovativeness and a variety of } \\
\text { indicators of skills, skill } \\
\text { requirements and training } \\
\text { activity in UK SMEs }\end{array}$ & $\begin{array}{l}\text { - Importance of intermediate technical skills rather } \\
\text { than higher level technology skills for innovation } \\
\text { performance } \\
\text { Innovation depends on acquisition and } \\
\text { development of sill not smply their presence } \\
\text { - Strong relationship between training intensity } \\
\text { and product/process innovation }\end{array}$ \\
\hline $\begin{array}{l}\text { Human Resources Development } \\
\underline{\text { Canada and OECD (1997) }}\end{array}$ & $\begin{array}{l}\text { Workplace strategies to deliver } \\
\text { better outcomes in a context of } \\
\text { technological and organisational } \\
\text { change. }\end{array}$ & $\begin{array}{l}\text { Bundles of organisational innovations including } \\
\text { training can result in better performance } \\
\text { Technologically and organisationally innovative } \\
\text { firms place a premium on highly skilled workers } \\
\text { and tend to pay them more }\end{array}$ \\
\hline Laplagne and Bensted (1999) & $\begin{array}{l}\text { Impact of general training and } \\
\text { innovation on the performance } \\
\text { of workplaces in Australia }\end{array}$ & $\begin{array}{l}\text { - Poor training is significant contributor to below } \\
\text { average productivity } \\
\text { Innovation performance a key contributor to high } \\
\text { productivity firms }\end{array}$ \\
\hline Leiponen (1996) & $\begin{array}{l}\text { Education and skill } \\
\text { characteristics of workforces in } \\
\text { innovative versus non } \\
\text { innovative firms }\end{array}$ & $\begin{array}{l}\text { Innovative firms have more educated workforce, } \\
\text { are more profitable than non innovating firms } \\
\text { and are more dependent on educational } \\
\text { competence for generating their profit } \\
\text { Com[lementarities exist between different } \\
\text { general skills acquired in tertiary education }\end{array}$ \\
\hline Albaladejo and Romijn (2000) & $\begin{array}{l}\text { The determinants of innovative } \\
\text { capabilities among UK small } \\
\text { firms }\end{array}$ & $\begin{array}{l}\text { The skill mix of a workplace (especially the share } \\
\text { of the highly educated) has a positive impact on } \\
\text { innovation performance } \\
\text { Owner's technical education and prior work } \\
\text { experience impact positively on innovation } \\
\text { performance }\end{array}$ \\
\hline
\end{tabular}

Source: own compilations from cited studies as well as those referenced within OECD (1998) and Descy and Tessaring (2005).

Both sets of international reviews had a similar focus in that they tried to establish not only productivity effects but also the distribution of accruing benefits, for example wage increases for employees or the value of training for the firm. Both included studies that were designed to reveal causal relationships, not just correlations, between training and productivity and both reported that whilst many studies reported measurable effects from training, not all of them did and that productivity increases were observed also in the absence of explicit training or capital investments. At the firm level, both sets of studies at firm level indicated that training on average had positive economic effects but that these effects were not universal; training did not automatically increase productivity and increasing productivity did not automatically translate into increased profitability.

These empirically based studies generally indicated that:

- innovative or innovating firms engage in more training than non innovating firms; 
- the skill composition of a firm's workforce is an important contributing factor but the type of skill-mix best suited to innovation performance is contingent;

- innovative or innovating firms spend more on training (both acquisition and development of skill).

\subsection{How to value and utilise skills for innovation success}

At the heart of the problem of how to design effective innovation policies aimed at skills and training is the difficulty of assigning an appropriate value to a particular stock of enterpriserelated skills or to estimate the prospective returns on an investment in training or the development of a bundle of human resource practices designed to encourage the steady accumulation of skills and expertise among employees or teams in an organisation. In particular:

- it is difficult to assess the quality of training programmes and the links to job prospects in advance;

- where employers invest resources, some of the benefits may be lost for that specific firm if the employees take up new jobs or are poached;

- there is 'asymmetric information' in the labour market for skills due to the lack of certification, namely a lack of recognition of acquired qualifications or skills making it difficult to 'inform' other market parties of the additional capabilities obtained; and

- it is difficult to finance education and training since it is an intangible and uncertain investment good that by its character cannot serve as collateral.

A major disincentive to training (especially in SMEs) appears to arise from the fact that neither employers nor employees can be sure of receiving an adequate return on investment in human capital due to market imperfections (Crouch et al. 2001, Miller 1996). For employers this is because of uncertainty about the productivity outcome of training as there is no body of publicly or commercially available information which allows firms to evaluate the future income likely to be generated by investment in training comparable to that available on investment in physical capital.

This is a crucial underlying reason why most OECD countries do not provide formal recognition of human capital as an asset in financial accounting and reporting systems at any level (Miller 1996). It is often thought that the reason why human capital cannot be treated as an asset by the firm is because individual employees can exit, but it is also a result of the fact that employment contracts are vague precisely because of the inadequate methods for measuring human capital and its outcomes. If the value of training was more adequately known, then long-term agreements between employers and employees about how to finance training would become possible. There is already widespread contractual agreement between employees and employers about the financing of training, but at present this is often conceptualised primarily as some form of loan, without explicit valuation of the training as an asset. This means that the creation of human capital is seen as a current expense rather than as an investment, creating an institutional disincentive to invest in human as opposed to physical capital. Miller's (1996) analysis (and confirmed by the OECD's (1998: 91-5) meta-analysis) lists several options for government policies to contribute to create a positive environment for human capital investment: 
- Strengthening market valuation of training and competences - A transparency and competence-based skills validation system would encourage both validation of prior learning and incremental addition of new modular skills, by providing greater assurance of later market valuation.

- Capitalisation allowing firms to collateralize and amortize knowledge - which could allow projection of skills depreciation and upgrade costs, and give some warning of obsolescence and natural loss through aging. Clear ownership allowing direct financing of knowledge acquisition - if clearly defined competences are linked to productivity outcomes the question of which party should finance training are greatly simplified

- Transparency of labour contracts as this would bring out both employee assets and employer benefits which are currently hidden. At a further stage of development of a transparency-based system skills can be treated as a leased asset for accounting purposes, allowing the employer to use depreciation accounting while the employee can more easily recover costs of acquiring or upgrading skills.

- Validation of alternative learning acquisition - a competence-based skills system could reduce artificial distinctions between formal and informally acquired knowledge. Identification of investment patterns - if training is recorded as an investment with relatively predictable outcomes it becomes possible to recognise patterns of 'over' or 'underinvestment'.

- Discouragement of 'unfair' rents, reduction of information 'noise' and discrimination this could reduce discrimination on the basis of prejudice and ascribed characteristics, benefitting marginalised groups and individuals enhancing entry to and mobility within labour markets.

\subsection{The costs and financing of training at enterprise Level}

Market imperfections and externalities affecting training referred to above have resulted in many countries (including the $\mathrm{UK}^{3}$ ) considering the introduction or extension of levies on firms to encourage investment in training. In a context of market failures in the provision of training, levies are regarded as a means of mobilizing additional resources for skills development. While levy type policies are generally not targeted directly at strengthening innovation capacity, they might be assumed to have a positive impact by boosting the skill base, particularly at the medium level. A review of country policies and their effectiveness highlight a number of issues. Levy schemes can increase the volume of training. Levy schemes can support the development of a wider network of infrastructure in skill and training. Levy schemes can be suitably adapted so as to provide targeted assistance or exemptions for small and medium-sized firms. Finally, levy schemes may be designed around either a universal model or highly differentiated reimbursement schemes depending on the perceived merits in particular situations of general versus specific skills, for example, or particular sectors of the economy. The key issues and country examples are summarised in table 2 .

Recent international reviews (e.g. Dar et al. 2003, EIM/SEOR 2005) of levy-grant schemes identify multiple forms:

The recent UK Leitch Review (2006: 79), for example, advocates a reinvigorated levy/grant system as a means of encouraging employers to engage training activities, to meet current needs and to enhance continuing vocational training and lifelong learning for skill formation. 
1. those where fund administrators use earmarked levies to distribute grants to employers for approved training, as in Singapore and previously in the United Kingdom;

2. training levy rebate schemes, where employers are partially reimbursed for approved training out of their payroll levies (Malaysia, Nigeria and the Netherlands);

3. levy exemption schemes where employers are exempt from levy payments provided they spend a given percentage of their payroll on training (France, Korea, and Morocco); and

4. tax incentives for approved training paid out of general revenues (Chile and previously in Malaysia) (Dar et al. 2003).

Levy schemes may cover all sectors of the economy or target specific sectors. They are extremely common within the EU - accounting for an estimated one in ten demand-oriented instruments for fostering workforce training (EIM/SEOR 2005). A number of countries have resorted to imposing payroll taxes on enterprises to contribute towards the funding of training in specialized institutions and/or in enterprises. The key principle behind such schemes appears to be that the beneficiaries pay: that is, while the cost of general training ought in principle to be shared with the trainees, employers should assume the bulk of firm-specific training costs. Payroll taxes are also attractive to governments because they provide a sheltered source of revenue for training and a means of mobilizing funds that may otherwise be unavailable to the public sector.

Data from the World Business Environment Survey (a survey of 10,000 firms in 80 countries 1998-mid 2000) reported by Batra et al. (2003) and Batra and Tan (2002) show that several East Asian economies have used direct reimbursement of approved training expenses, funded through payroll levies, to encourage firms to train their employees. Successful schemes evaluated were shown to be flexible, demand-driven, and often accompanied by an information campaign and technical assistance to smaller firms (see box 1).

Box 1: Country examples of direct reimbursement of training

TAIWAN; The introduction of such a scheme in Taiwan (China) led to dramatic increases in training, which continued after the program ended in the 1970 s

SINGAPORE: Uses a levy on the wages of unskilled workers to upgrade worker skills through the Skills Development Fund: to raise awareness of training among firms, to support development of company training plans, and to provide assistance through industry associations. There has been a steady rise in training, especially among smaller firms.

KOREA: Scheme required training last a minimum of six months or that firms pay a fine, many firms paid the penalty rather than train to this standard so acted as a disincentive. However grants for developing training plans, organized regional courses on training need assessments, and a variety of subsidized programs targeting small enterprises indicate that these aspects of scheme have increased the incidence of training in enterprises.

MALAYSIA: Human Resource Development Fund (HRDF) set up in 1993 with matching grant from government. Eligible employers with 50 employees and above are required to contribute 1 percent of payroll to the HRDF. Those who have contributed a minimum of six months are then eligible to claim a portion of allowable training expenditures up to the limit of their total levy payments for any given year. The HRDC set rates of reimbursement, varying by type of training and generally lower for larger firms Impact studies not available

Source: Batra and Tan (2002). 
Table 2: Levy schemes, policy lessons and country examples

\begin{tabular}{|l|l|l|}
\hline $\begin{array}{l}\text { Relevant features of } \\
\text { levy schemes }\end{array}$ & Policy Lessons & Country Examples \\
\hline $\begin{array}{l}\text { Compulsory } \\
\text { economy- wide } \\
\text { application }\end{array}$ & $\begin{array}{l}\text { Maximum impact on increasing training volumes } \\
\text { Engagement of social partners facilitates building a } \\
\text { strong reputation }\end{array}$ & France - training levy \\
\hline $\begin{array}{l}\text { Positioning in wider } \\
\text { skill formation system }\end{array}$ & $\begin{array}{l}\text { Can support the wider development of } \\
\text { skill/training infrastructure } \\
\text { Increased expenditures directly boosts the } \\
\text { development of a market (public and/or private) } \\
\text { for training provision }\end{array}$ & Japan and Korea \\
\hline Coverage of SMEs & $\begin{array}{l}\text { SMEs least likely to invest in training therefore need } \\
\text { targeting } \\
\text { Need to balance unwelcome costs versus targeted } \\
\text { subsidies }\end{array}$ & $\begin{array}{l}\text { Australian construction } \\
\text { sector }\end{array}$ \\
\hline $\begin{array}{l}\text { Differentiated } \\
\text { schemes }\end{array}$ & $\begin{array}{l}\text { Schemes can be designed to reduce employer bias } \\
\text { against training in general skills } \\
\text { Differentiation in fees/ reimbursements possible by } \\
\text { sector, firm size, firm age }\end{array}$ & $\begin{array}{l}\text { Malta, UK construction } \\
\text { sector }\end{array}$ \\
\hline
\end{tabular}

In France ${ }^{4}$, the training levy has been in continuous use since 1925. In 1971 the Further Training Act stipulated that French private companies (with more than 10 employees) spend $1.6 \%$ of their wages and salaries bill on further training activities or pay the equivalent into funds set up for this purpose. A minimum of $0.9 \%$ had to be allocated to a training plan drawn up and implemented by the employer, while $0.7 \%$ had to be allocated to various types of compulsory contribution (e.g. individual training leave, sandwich courses for young unemployed people). France also uses payroll tax exemption and firms can reduce or eliminate their levy obligations by the amount of training they provide or purchase. It is assumed that as firms know what their training needs are, they will spend their money on appropriate training programs. In France under the levy-exemption scheme and also in Singapore through the Skills Development Fund, the amount of training undertaken by employers increased (Kuruvilla (2000) and Tzannatos and Peresesson (2000) cited in Dar et al. (2003)). There are criticisms of the French universal levy in terms of effectively increasing enterprise based training, Giraud (2002) reports that despite having a national training levy, only 58\% of French workers reported receiving further training compared with $84 \%$ of workers in Germany, where no such levy is enacted. It seems that there can be no guarantee that mandated levies will produce higher levels of participation in enterprise-based training.

Another form of levy are matching grants schemes which are reported as having been successful (Batra and Tan 2002) in supporting the development of a training culture. This has been achieved by providing an incentive and a means of investing in training thus encouraging a high level of training capacity in enterprises and a high propensity for workers to undertake training. The Basic Law for Vocational Training (1976) in Korea, for example, was designed to encourage in-company training by designating funding for training as a percentage of company wage bills.

4 See Greenhalgh (2002). 
Strong training cultures have been established using such schemes, in some Asian countries (Japan, Korea, Singapore) and in some northern European countries (Germany, Netherlands, Scandinavia). A reported side benefit has been the development of a network of industry management training consultants that are available to enterprises that want to invest in enterprise-based training. Singapore has undertaken a program to build up its stock of industry trainers, and Japan's Industrial and Vocational Training Association has trained over 30,000 industry trainers in the past 30 years. In Japan most managers have a training function, and regularly engage workers in informal training. However, Batra and Tan (2002) found that a matching grants scheme alone will not lead to an expansion of the training market if such grants are restricted to state-run training institutions. They argue that funds should support strengthening and diversifying the supply of training and stimulating demand.

There are many other differentiated mechanisms for distributing training funds: directed selectively to enterprises on the basis of training plans (Germany, Korea, Singapore), or distributed through open tender, with the state as purchaser rather than supplier of training (Australia, Chile). A different pathway has been the use of user or trainee voucher schemes, such as the United Kingdom Training Credits scheme. In addition, in the UK there are currently two Industry Training Boards with the power to raise levies to subsidise training in their industries: the construction ITB (CITB) and the engineering construction ITB (ECITB). Levy rates are based on $0.5 \%$ of direct labour payments (PAYE) and $1.5 \%$ on labour-only sub-contract payments (LOSC). Small firms, whose wage bill is below the threshold level of $£ 73,000$, are exempted from paying the levy.

Training grants issued to UK construction companies are diverse and come under the following categories: 'new entrant training' (NET) for young apprenticeships; 'adult craft' for new-entrant adults as well as existing workers; 'plant' for plant operatives; 'management' for management training, such as site management and safety training courses; 'qualifying workforce' for certifying the skills of the existing workforce, which includes schemes such as On-Site Assessment and Training (OSAT); and 'training plans' for supporting the development and implementation of a company training plan (CITB 2002).

There is currently no clear assessment of the impact ${ }^{5}$ of the UK CITB ${ }^{6}$ and ECITB levies in terms of skill transfer to the workplace and potential contribution to business performance and whether such schemes have maintained a training base in industries characterised by contract labour and high turnover. Both industries are ideal for testing the validity of both employers' claims and government skills policy assumptions, because of extensive coverage of the levy and, not least, because these sectors will be significant in the greening of the infrastructure (requiring new and adapted workforce skills).

Many sectoral training funds exist in the Netherlands that are financed by levy systems and used to subsidise training activities (a similar role for sectoral agreements on training funds financed by levies is present in Belgium and Denmark). Companies can recover part of their training costs through a subsidy of the Education and Development Fund ( $0 \& 0$ fondsen) of their particular sector or branch. The funds are based on levies of all firms covered by the collective

${ }^{5}$ UKCES UK Commission on Employment and Skills has a forthcoming assessment www.ukces.org.uk/

${ }^{6}$ CITB site for further information http://www.cskills.org/levy-grant/index.aspx 
agreement under which the fund is established. The levies vary by sector and range from $0.1 \%$ to $0.7 \%$ of the gross wage bill. The $0 \& 0$ funds are used to finance individual training leaves, and support training programmes detailed in training plans submitted by employers. The fund may support up to $50 \%$ of the costs of a training programme, and award collective training days for a certain sector (Trampusch et al. 2010).

In the Australian construction industry a training fund exists funded by a levy of around 0.1$0.2 \%$ on building value. In many cases these funds have been used to support apprenticeships in the industry and have not been used widely for continuous vocational training (Stone, 2010).

There are few robust impact assessment or evaluation studies of these policy instruments and the true impact - in terms of ongoing skill formation, business performance and productivity and innovation - cannot therefore be elaborated because of this. The EIM study (2005) which covered these schemes across the EU, found that:

- tax schemes had the advantage of building on existing institutional arrangements allowing companies to apply for the incentive with limited additional administrative costs;

- the conditions for applying were usually very transparent and straightforward but that the checking of applications afterwards is, not very intensive. This is because the volume of applications is often high and the checking is done by fiscal authorities not specifically specialised in training policy issues;

- the advantage of limited conditions may be linked to high deadweight loss of these tax deductions, because targeting and conditions for additionality are limited (not empirically tested);

- relatively limited conditions and high deadweight losses are expected to apply to levies, although there is little research about the effectiveness of levies in various countries, in spite of the fact that they play a central role in the training system of many countries; and

- from a public spending viewpoint, levies are - compared to fiscal deductions - much cheaper, because in essence it is a transfer of money from companies with low investments in training to companies with high investments and in that sense a counterbalance to market imperfections.

The study by Johanson (2009:14) adopts a global perspective and emphasises the importance of understanding the context in which these instruments operate. It arrives at similar conclusions generalised in Table 3. 
Table 3: Advantages and limitations of levy systems

\begin{tabular}{|c|c|}
\hline \multicolumn{2}{|c|}{ SOME ADVANTAGES } \\
\hline • & $\begin{array}{l}\text { Earmarked payroll levies can be viewed as "benefit taxation," - those that benefit(employers and workers) pay for the } \\
\text { training }\end{array}$ \\
\hline • & Levy systems can augment substantially the resource base for training. \\
\hline - & Increased training resources in turn can substantially increase the incidence of training \\
\hline • & $\begin{array}{l}\text { Levies can provide a steady and protected source of funding for training, particularly in the context of unstable public } \\
\text { budgets. }\end{array}$ \\
\hline • & $\begin{array}{l}\text { Levy-grant systems can encourage firms to intensify their training efforts, increase training capacity and raise training } \\
\text { quality. }\end{array}$ \\
\hline • & $\begin{array}{l}\text { Training levies collected from formal sector employers can serve as a vehicle for cross subsidization, e.g. for smaller } \\
\text { employers and especially for firms in the informal sector. }\end{array}$ \\
\hline • & $\begin{array}{l}\text { Funds with tri-partite management can forge cooperation among the social partners and facilitate formulation of } \\
\text { appropriate training policies. }\end{array}$ \\
\hline • & $\begin{array}{l}\text { Funds can influence the quality of training through accreditation procedures and helping to stimulate a competitive } \\
\text { training market. }\end{array}$ \\
\hline • & $\begin{array}{l}\text { Levy-financed funds can also help correct imbalances in training access by pooling funds - e.g. for training } \\
\text { disadvantaged segments of society, unemployed, those in the informal sector. This redistribution can be termed "cross- } \\
\text { subsidization." }\end{array}$ \\
\hline • & $\begin{array}{l}\text { Establishment of a separate training fund account can facilitate transparency and minimize distrust between employers } \\
\text { and the public sector }\end{array}$ \\
\hline \multicolumn{2}{|r|}{ SOME LIMITATIONS } \\
\hline$\bullet$ & $\begin{array}{l}\text { Earmarked taxation does not conform well with the principles of sound public finance and weaken attempts to unify the } \\
\text { national tax system. }\end{array}$ \\
\hline • & Payroll levies raise the cost of labor to the employer, possibly discouraging employment. \\
\hline • & $\begin{array}{l}\text { Employers may shift the incidence of the levy on to workers in the form of lowered wages; in this case workers and not } \\
\text { the employers bear the burden of tax, }\end{array}$ \\
\hline • & $\begin{array}{l}\text { Insecurity of income: Under fiscal pressure, government may divert levy proceeds into general public tax revenues for } \\
\text { non-training uses }\end{array}$ \\
\hline • & $\begin{array}{l}\text { Unequal access: many firms, particularly small ones, do not benefit from the scheme; this breeds resentment, } \\
\text { opposition and compromises the status of training levies as "benefit taxation" }\end{array}$ \\
\hline • & $\begin{array}{l}\text { Inefficiency: Payroll levies may constitute an over-sheltered source of funding, leading to unspent surpluses, } \\
\text { inefficiencies and top-heavy bureaucracies }\end{array}$ \\
\hline • & Red tape may erect high barriers for firms to access funds \\
\hline
\end{tabular}

Source: Johanson (2009:14).

Subsidised work-based training in Britain, for example, has also focused on subsidies to employers delivered through the now discontinued Train to Gain (T2G). A National Audit Office (2009) report on T2G cited survey-based evidence which indicated the level of deadweight in the scheme at around 50\%. A study by Mason and Bishop (2010) found that government programmes such as $\mathrm{T} 2 \mathrm{G}$ aimed at increasing qualifications levels for the least qualified were effective. However, they had operated in a less than ideal UK labour market context where declining levels of employer commitment to training had been witnessed, as evidenced by a reduction in the average level of job-related training over the decade investigated.

The findings from international experience (Batra et al. 2003, Batra and Tan 2002, Dar et al. 2003) suggest the following lessons from experience with levies:

- Countries which had vested supervision of levies in industrial bodies had more successful outcomes than those that did not;

- Levy funds were not cost-effective when they supported only government training providers so policies should be designed to increase competition in training provision;

- Funding levels are better maintained with levies than with government grants which tend to decline with shrinking budgets;

- These schemes have typically been used by large firms and enterprises that already have a high skills base-so more defined and rigorous support mechanisms are needed for small and medium firms to participate; 
- Levies may be particularly appropriate for micro-firms or self-employed contractors in highly fragmented industries which are geographically dispersed;

- Training in small firms is relatively sensitive to the availability of subsidies - as its incidence rose significantly in those enterprises assisted - where both qualified and unqualified workers were found to have received training; and

- These schemes are more effective under conditions of economic growth.

\subsection{Policies for high-level skill formation}

In the area of higher skills, a key preoccupation for policy-makers and practitioners, is the extent to which tertiary education can effectively meet employers' demands, particularly in innovative sectors of the economy, It has been long been understood, particularly in practice associated with apprenticeship and technical trades education, that emphasis only on classroom learning and separation from the workplace means that learning is de-contextualised and is only indirectly related to outside work (Stern et al. 1996). Workplace learning and forms of instruction, reflected in curricula, combining experiential and cognitive learning are recognised as an effective means of skill formation and acquisition (Rubenson and Schuetze 1995). A key question now at the higher skill level is how to produce and develop highly trained individuals (at both graduate and post graduate levels) who have a mix of general problem-solving abilities and scientific/technical skills, combined with some experience of the challenges of business and project management.

University-industry (UI) collaborations and partnerships seek to address this area. They have existed for some while and continue to be developed as part of innovation policy strategies. The Industrial Liaison Program (ILP) ${ }^{7}$ set up in 1948 at MIT is an early example of formalization of such links (Chesbrough 2003) and other examples include, Cooperative Awards in Science and Engineering (CASE) \& Knowledge Transfer Partnerships (KTP) ${ }^{8}$ - in the UK: the Industrial Research Programme ${ }^{9}$ - in Denmark; the CIFRE Programme ${ }^{10}$ (Convention Industrielle de Formation par la Recherche) - in France.

Many universities in Europe have a history of combining academic studies with workplace experience. Research by the Open University shows that participation in work placements, for example, is as high as $84 \%$ in France (compared to $30 \%$ in the UK), and there is almost universal participation in internships among students enrolled at vocational universities in the Netherlands (Attwood 2010). In the US, approximately 500 institutions offer what is known as 'co-operative education' in which work placements are combined with university study. Work placement participation rates in the UK are low with a downward trend in the number of sandwich courses happening between 1994 and $2007 .^{11}$

Underpinning many developments in UI partnerships has been the steady rise in the production of individuals holding doctorates (also a focus of innovation policies) and the growth in researcher employment in some countries. Denmark, Finland, Iceland, New Zealand and Sweden have had the biggest shares of researchers in total employment: there were more than 16 researchers per 1,000 employees in Finland in 2009 (OECD average of less than 8). Japan, the

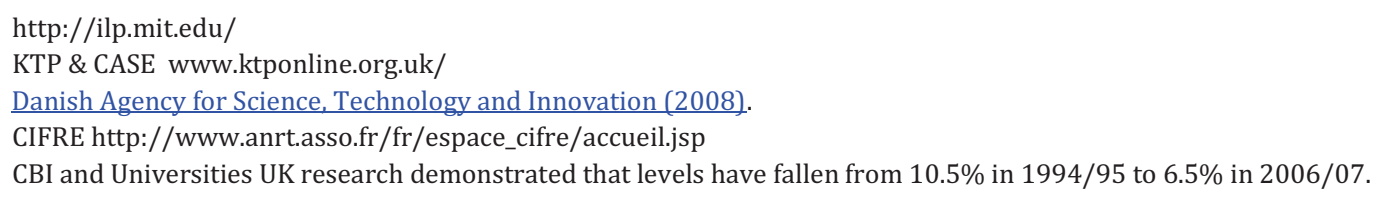


Russian Federation, Korea, Germany and France had the biggest groups of full- and part-time researchers (along with China in FTE terms). Australia, Canada, China, Denmark, Japan, Korea, Sweden and the United States when measured in FTE units had more than $60 \%$ of researchers employed in the business sector (OECD average 63\%). ${ }^{12}$ Such patterns reflect a country's industrial structures and the scale of R\&D-intensive sectors. They indicate a pool of highly qualified talent available to expand UI collaboration and thus possibilities for developing new ways of "doing" research for wider added value through different forms of doctoral education, mobility patterns, changing career configurations and new collaborative techniques for UI interaction, including joint training and skills development as well as funding arrangements (Box 2011:6). The university industry interface, how it works across many dimensions by allowing a mixture of internal resources and external partnerships is viewed as an important source of innovation in the move towards more research intensive economic activity (Zucker et al. 2002, Bodas Freitas and Bekkers 2007, European Commission 2006, Perkmann and Walsh 2007).

The literature on UI collaborative approaches both theoretical and empirical is very wide. Much of it is descriptive, hypothesizing and not particularly illuminative of the "actual processes by which universities [affect] the rate and direction of technological change in industry" (Ponomariov and Boardman 2012:11). Three extensive studies by Thune (2007, 2009, 2010) and the recent OECD working paper (Ponomariov and Boardman 2012) on graduate and postgraduate UI collaboration schemes (i.e. human resources for public to private knowledge transfer), in great part derived from Thune's work, have proved useful, although not specifically targeted on human resource skill training. These sets of studies, it should be noted, do emphasize the difficulty of measuring the impact of UI collaborative arrangements across many factors such as institutional cultures, issues related to intellectual property and outcomes, effect on company products, organizational change and profits and training approaches.

However, Thune's review of studies does offer some useful insights on outcomes related to human resource formation both at graduate and post graduate levels, within UI collaborative schemes.

- UI graduate students (from the studies - mainly in engineering, life sciences and natural sciences) have different researcher training compared to non UI graduates.

- This is because they are exposed to a much more heterogeneous learning environment than non-UI graduates where there is a greater demand for more diverse skills including those of management.

- UI collaboration results in new forms of graduate research training because the context has been widened beyond the traditional confines of academe - also resulting in transformative research across disciplines and domains and expansion of wider knowledge networks.

- Outputs for UI and non UI students in terms of research productivity (e.g. publications) are fairly similar.

- Analyses have not been fully drawn of the significance (or not) of the type and size of firm or the formal or informal character of collaborations in terms of impact on UI programmes, their shape and design and curricula content.

$12 \operatorname{OECD}(\underline{2008 \mathrm{a}}, \underline{2008 \mathrm{~b}})$. 
- The type(s) of innovation a firm is involved in and the firm's innovation strategies are both connected to expectation of outcomes from collaboration - in terms of supervision, communication and project management but this is again not fully understood.

- Career outcomes and future trajectories as a result of UI human resource collaboration schemes are similarly not fully understood although UI graduates have a stronger likelihood of private sector employment than non UI graduates but this may be in large part because of expectations and experiences of UI graduates (they choose in the first place to collaborate with industry because they eventually want a career in private sector research/ management, for example): in any case there are implications for a changing scientific labour market.

Findings from the Thune reviews are summarized in the following table in order to demonstrate the scope of the studies. 


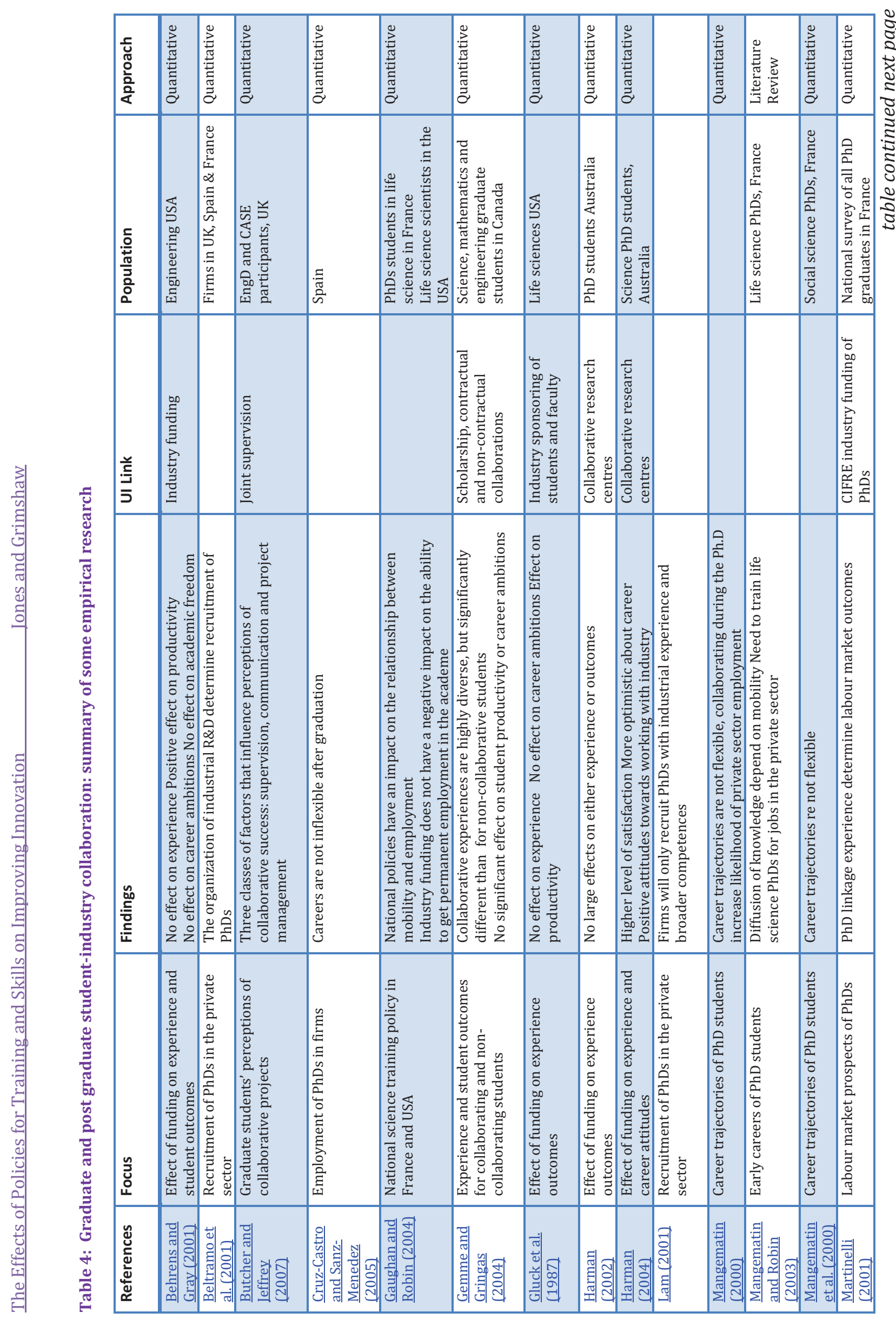

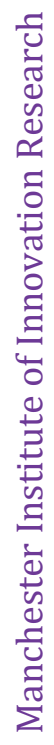




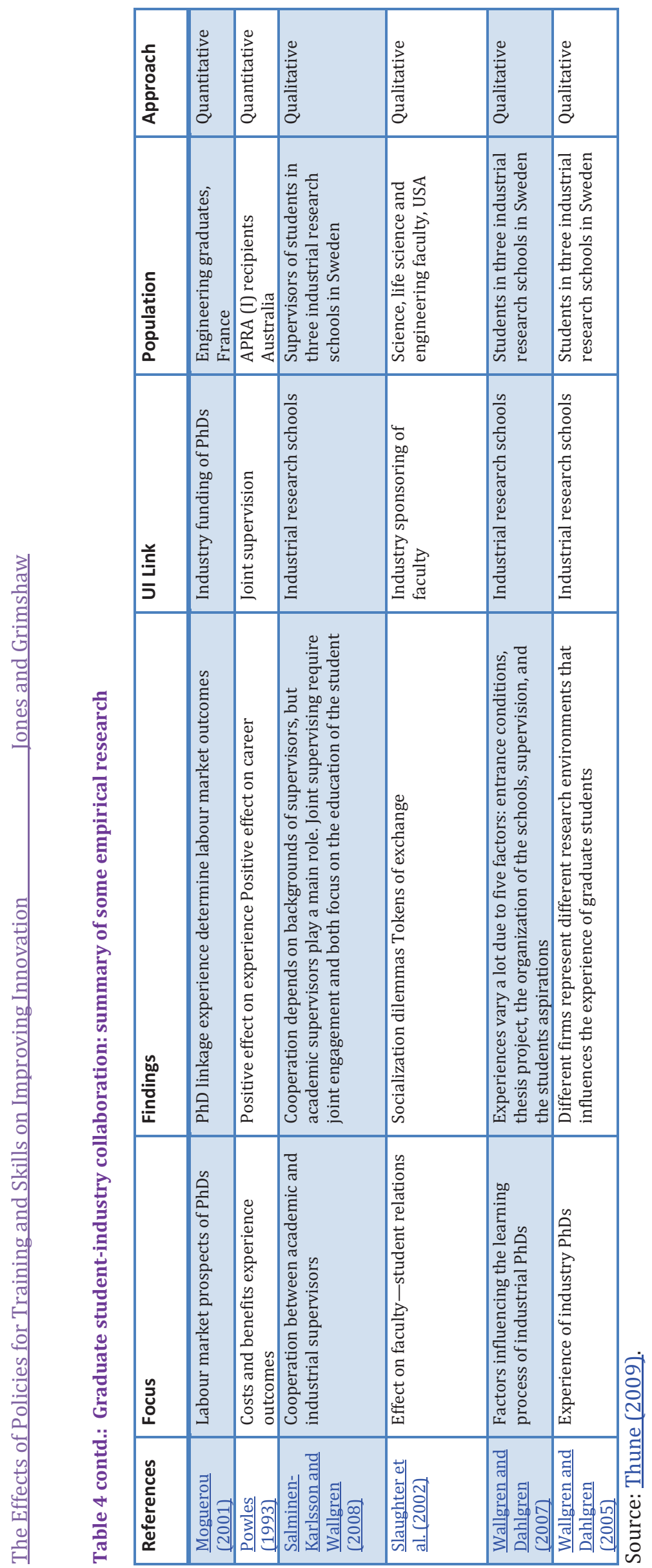

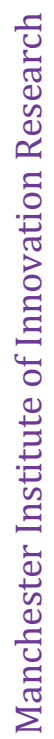


Policies across Europe provide further examples of initiatives in the areas of human resource oriented UI collaboration and the shaping of different types of doctoral equivalent levels. The EU Marie Curie Action programme includes industrial doctorates in all fields of research and requires the joint participation of an academic and industry partner and the 50\% placement of the doctoral researcher in the participating company. In Denmark, an Industrial PhD programme - financed by the Danish Council for Technology and Innovation and administered by The Danish Agency for Science, Technology and Innovation - has been established as a research training programme with an industrial focus and managed jointly by a private company and a university (Danish Agency for Science, Technology and Innovation 2008).

Similarly, in France, Industrial Agreements for Training Through Research (CIFRE) is a programme to develop collaborative research partnerships based on joint financing agreed between participating companies and the National Association for Research and Technology (ANRT). As with the other programmes, the French CIFRE programme seeks not only to give companies access to cutting-edge public research, but also to help the students achieve a foothold in the company to improve their future job prospects (see Kitagawa 2011). The French National Association for Technology Research (ANRT Ministry of Research and Technology), through the CIFRE programme, supports doctoral UI collaboration whereby a $\mathrm{PhD}$ candidate can be hired for a firm for a three year period.

The French CIFRE programme can be viewed as a tool of innovation policy to enable coproduction and transfer of knowledge and competences. A CIFRE student spends time between the UI and can contribute to technology transfer through the thesis topic. An econometric study by Giret and Recotillet (2004) surveyed a nationally representative sample of PhD graduates (n.1744 across Engineering Mathematics, Physics Chemistry Law, Economics and the Humanities) three years after they graduated in 1999 to examine the impact of the CIFRE programme's stated aim of improving labour market entry for doctoral researchers into industry. The study pointed out that the traditionally specific patterns of transition from school to work for young PhDs meant entry into the public research sector had created a narrow and highly competitive labour market for early career researchers based on fixed-term contracts and restricted long-term employment prospects for many researchers. This approach has meant that many, particularly in the sciences, were unable to gain entry into the public research sector even on fixed-term contracts and their high level skills in research were thus lost.

The study nevertheless showed that CIFRE UI doctorates three years after graduating mostly enjoyed a better labour market position than non CIFRE doctorates in terms of gaining research employment and higher wage levels. The latter may be explained by wider prospects in the private sector. During the three years of the programme as the graduates mainly worked in the firm R\& D departments, the general abilities and academic knowledge in the industrial setting were maintained and enhanced and in addition were combined with the management, organizational and social skills considered as essential attributes for research activity and application in R\&D functions (aptitude for team work, creativity, critical thinking). The study found that the CIFRE programme in general was a successful instrument for promoting and developing UI collaboration in that it perhaps represented a new intermediation space (p:5) where co-production of knowledge and transfer essential to innovation processes could take place. 
In the UK higher education sector some recent interesting developments involve the design of new undergraduate degrees and doctoral level initiatives in partnership with industry and sector skills councils. Although evidenced outcomes are not yet available, three examples are worth noting for future reference. A first high profile example is the new Information Technology Management for Business (ITMB) undergraduate degree, the first IT undergraduate degree to be devised and delivered by employers in collaboration with universities. The national Research Councils are also implementing innovative initiatives designed with structures that seek both to establish knowledge flows between academia and industry and to enhance high-skill, collaborative working in innovative growth areas where the UK is proven to have a strong competitive position. Initiatives in the area of biotechnology and biological sciences are illustrative. Thirdly, the Engineering and Physical Sciences Research Council (EPSRC) has been pioneering similar schemes through their Industrial Doctorate Centres (IDCs). ${ }^{13}$

The significance of these types of partnership schemes between employers and universities may be their recognition of the value of human resource formation in terms of skills, knowledge and expertise acquired in the workplace which can be validated at the tertiary level of education, whether through undergraduate degree programmes, postgraduate Masters level courses or business-related professional doctorates. In the three cited examples, knowledge transfer and diffusion is said to be enhanced via cluster networks into the wider sector communities. Importantly, the strategic direction for many of the programmes is formulated through Industry Advisory Boards comprising representatives from professional bodies, employers, and regulators and in some cases, International Steering Committees to ensure global relevance.

Such Industrial and Professional Doctorates may to some degree represent a new form of dynamic workforce skills enhancement that could provide long-term incentives and sources of workplace innovation (OECD 2010 cited in Kitagawa 2011). The nature, however, of the processes of human resources formation in terms of skill and what comprises the essential characteristics of both the processes and essential elements of skills formed in these new spaces of collaborations is as yet under-researched. Kitagawa (2011) has proposed useful areas for future research which could be developed with the appropriate methodologies (specific to the sectors and disciplines). Her questions for discovery include:

- What kind of skill formation (for example new types of skill) is taking place?

- What kind of knowledge diffusion networks or channels are contributing to the collaborative skill formation process?

- What are the outcomes, if any, for the practice of academic research and research application development within companies?

An extensive Europe based study known as DOC-EU of UI partnerships has delivered findings about existing practice in industry based doctoral programmes (Borrell-Damian 2009). The study covered 82 organizations across 20 European countries and different sectors - (three specific areas were selected for special study - Science, Engineering and Technology (SET), Biotechnology, Medical and Life Sciences (BML), Economics and Social Sciences (ESS). These included 33 universities, 31 companies and 18 other stakeholders including university and professional networks, government bodies, university-industry interface organizations and

13 The schemes operating under both BBSRC and EPSRC do so with funding via the research councils and financing from the industry sectors involved. The STREAM programme cost, for example, over 5 years is $£ 10.2 \mathrm{~m}, £ 4.4 \mathrm{~m}$ of which is being invested by the water industry and $£ 5.8 \mathrm{~m}$ from EPSRC. 
other higher education organizations. Case studies presented in this project suggested that $50 \%$ of current doctoral holders are employed outside academia, holding both research and non-research positions in businesses, governments, service sectors and other education sectors (p. 7) and also highlights that not all doctoral candidates can or want to work in academia; doctoral-level education is simply seen by some individuals as the best possible training in their field and as good preparation for a variety of career paths (ibid, p. 71).

In the area of skill capabilities for UI collaboration the DOC-EU study confirms a generally held view that doctoral candidates in addition to their core research skills need to develop transferable or integrative skills as industry values $\mathrm{PhD}$ holders with strong communication, negotiation and management skills, in addition to deep domain knowledge and a capacity for complex problem solving. Table 5 indicates the approach of the European Science Foundation as to what these skills should comprise.

Table 5: Skills in an innovation context

\begin{tabular}{|l|l|}
\hline Skill types & Competencies included \\
\hline Interpersonal & $\begin{array}{l}\text { Working with others/teamworking - Mentoring and supervisory - Negotiating - } \\
\text { Networking }\end{array}$ \\
\hline Organisational & Project and time-management - Career planning \\
\hline Research & $\begin{array}{l}\text { Grant application writing skills - Research management and leadership- Knowledge } \\
\text { of research methods and technologies beyond the Doctoral project - Research ethics } \\
\text { and integrity }\end{array}$ \\
\hline Cognitive & Creativity and the ability for abstract thought - Problem solving \\
\hline Communication & $\begin{array}{l}\text { Communication/presentation, both written and oral - Communication/dialogue with } \\
\text { non-technical audiences (public engagement) - Teaching skills- Use of science in } \\
\text { policy-making }\end{array}$ \\
\hline Enterprise & Entrepreneurship* Innovation- Commercialisation, patenting and knowledge transfer \\
\hline
\end{tabular}

Source: adapted from ESF (2009) cited in Box (2011).

However, the DOC- EU findings were ambiguous in that consensus was not achieved on what kind of skills training should be a structural element of doctoral education. SMEs placed a higher value in doctorate holders with the so-called "soft skills" to complement their research capabilities at the moment of being employed. For large R\&D companies, the value of hiring a doctorate holder usually lay, in the first instance, in a deep knowledge of a relevant subject and broader competencies that are likely to equip the person to handle subsequent career challenges. The DOC study did not throw up findings which indicated thoroughgoing detailed analyses of what kind of skills bundles will be needed in doctoral education for future innovative work. An interesting study by the Institute for the Future ${ }^{14}$ sponsored by the University of Phoenix in this regard has speculated that "global connectivity, smart machines, and new media" (Institute for the Future, 2011:1) will require a different kind of vocabulary (and one more deeply pertinent than the ESF recommendations) when talking about and understanding the complexity of needed future skills which include sense-making, social intelligence, novel and adaptive thinking, cross cultural competency, computational thinking, new media literacy, trans-disciplinarity, new design mindsets, cognitive load management and virtual collaboration.

The study did find however, that in all sectors and fields, independently of how well-organized a collaborative programme was in formal terms, success also depended upon the quality of the

${ }^{14}$ http://www.iftf.org/ 
personal component, including the ability to team up to solve problems, achieve excellent performance, and establish good levels of mutual trust between the stakeholders. A common pattern of what was important for impact emerged from the different configurations of the collaborative doctoral programmes identified, which can be summarised as:

- the strategic level of engagement in the parent organizations;

- the role of industrial partner, in designing the collaboration;

- careful selection of the doctoral research topic;

- additional admission requirements although these were not clearly specified;

- formal agreements maintained (including Intellectual Property Rights); and

- clarity as to legal status of the doctoral candidate.

This extensive study found that next to the role of the external partner as part of the supervisory team, mobility through placements in industry is a major contributor to the training (and the consequent development of skills) of a doctoral candidate wishing to obtain insight into the business world and to the wider task of seeking additional value through effective UI configurations.

It is as yet unclear as to whether these sorts of schemes are sufficiently similar in their design and operation so as to facilitate lessons for cross-national policy transfer in order to improve policy interventions in different national context. Further research could determine the value of these approaches as tools for policy interventions aimed at increasing innovative capacity through unique skill formation pathways and the validation of industrial expertise at postgraduate qualification level.

We are not aware of any empirical studies that have undertaken an impact evaluation of the sort of high-skill, collaborative activities described above with respect to the contribution to innovation or productivity.

However, there are studies that have analysed the nature of trajectories in the development of higher education systems in Europe and their broader implications (Enders 2005). According to Enders, what may be emerging is a hybrid model that will cross disciplinary and organisational boundaries. These developments may, in turn, generate varied and complex organisational and structural forms, validation criteria and procedures that will transform systems of research training and high skill formation. The implications for policy formation are unclear and further investigation is required.

Additionally, lessons for policy may perhaps be drawn from studies of Nordic and other European countries as to the efficacy of policy approaches to support the work of post doctoral researchers (and in the process further develop their skills) who are active participants in development projects carried out in companies (Alasoini 2005, 2009; Alasoini et al. 2005). The studies are descriptive rather than evaluative. They indicate that where programme competitive funding is provided for the active implementation of change within individual firms, or within networks of organisations, where employees work collaboratively with outside researchers or experts there appeared to be more receptivity within the firm to the adoption of 'proinnovation' organisational practices. These included practices related to firm training and the formation of new skills sets. The success appears to be related to the fact that the collaboration avoids the risk of external researchers proposing universal best practice solutions that are likely to be poorly adapted to the local technological or organisational context (op. cit.). The studies also reveal indications of limited spill-over effects to a wider population of firms as successful 
activities carried out in a limited number of firms became known through firm-to-firm networks.

\section{Conclusions}

It has been argued cogently that skills requirements for an innovation context are more demanding in multiple contexts particularly in the combination of technical disciplinary expertise with a broad of range of business, management and social skills and problem solving skills across domains (Lam 2001). A decade after this statement the multiple contexts Lam notes have become ever more complex requiring skills (and implied training approaches) that are not quite reflected in the ESF matrix listed above (table 5) nor perhaps in innovation policies aimed at training for (future) skills for innovation in high skilled research centred economies. The findings in this report suggest there is a lack of attention in the innovation literature to the question of how we theorise and empirically analyse the multiple linkages between the components of skill formation systems and their varying innovation effects.

Many countries face challenges in their efforts to develop and utilise higher level skills for sustained economic growth. High unemployment, reduced job prospects and falling real earnings during the ongoing economic shocks mean that returns to educational investments are placed at risk and increasing numbers of workers report having under-utilised skills in their job: uncertainty over the rebalancing of the economy makes strategic investments difficult (see Box 2011, Rodríguez-Pose and Vilalta-Bufi 2005). Higher education, for example, can be viewed as a positive force and a solid foundation upon which to identify lessons for further policy development.

Overall we can derive the following lessons for innovation impacts:

- Strengthened collaborations between industry and higher education institutions characterise many of the recent national policy initiatives but the question as to how these are impacting upon innovation requires detailed investigation;

- Targeted partnerships offer innovations in training provision and contribute to the wider goal of adapting and delivering high level skills for fast-changing industry needs;

- More flexible pathways between educational institutions and workplace training programmes appear to have positive outcomes for adaptability and raising of skill levels;

- Longer-term programmes of financial investment and the principles of governance of skill formation systems help in generating stability and certainty, which encourage fuller participation of the relevant stakeholders;

- While the innovation impact of training levies is uncertain, country evidence does suggest they set a minimum floor for training investments which may be valuable for countries where there is wide variation in skill development by sector.

There are strong indications that further empirical analyses to inform future policy design are needed to:

- Understand the innovation consequences at firm level of targeted, sector-based investments in skill and training - in terms of what types of investments work, under what conditions of stakeholder participation and what sector conditions; 
- Consider the roll-out of a programme of skill-innovation evaluations delegated to sector skill councils to explore the relationship between employer commitment to training and innovation performance across different sectors;

- Assess in a cross-country comparative context the effectiveness of training levy/grant schemes for innovation performance - for example, what are the relative merits of schemes that seek to stimulate enterprises to undertake more skill development, as opposed to 'training credits' made available directly to adult workers who fall below a certain level of skill or require updating in new skills?;

- Research various methods that might improve the capacity of organisations to assign value to their skills-base and training investments in a manner that complements their investments and valuing of innovation performance - for example, by encouraging changes in financial accounting and reporting practices and related institutional arrangements.

The findings in this report may have implications for transversal policy approaches to take account of the interconnections between learning, innovation and the different institutional sub-systems of the knowledge-based economy across sectors and research and development disciplines. These include the connections among business-to-business subcontractor networks, strategic alliances, partnerships and clusters, educational providers and policy makers. This combining of different activity systems has been referred to as 'the crossing of structural holes' (Burt 1995) or 'boundary crossing' (Engeström 2005) and would appear to be particularly central to future policy development in the fields of higher education and collaborative relationships with industry. 


\section{References}

Abreu, M., Grinevich, V., Kitson, M., Savona, M., 2010. Policies to enhance the 'hidden innovation' in services: evidence and lessons from the UK. The Service Industries Journal, 30(1): 99-118.

Alasoini, T., 2009. Skill and Competence Development Through a Workplace Development Programme - Finnish Experience. Centre for Research in Lifelong Learning- Forum Report Number 21: Glasgow.

Alasoini, T., 2005. Learning networks as creators and disseminators of generative results, in Alasoini, T., Ramstad, E. and Rouhiainen, N., The Finnish Workplace Development Programme as an Expanding Activity: Results, Challenges, Opportunities. Report 47, Helsinki (pp. 136-168).

Alasoini, T., Ramstad, E. Hanhike, T., Lahtonen, M., 2005. European programmes on work and innovation: a benchmarking approach. Work-in-Net Project.

Albaladejo, M., Romijn, H., 2000. Determinants of innovation capability in small UK firms: an empirical analysis. Eindhoven Centre for Innovation Studies, The Netherlands.

Amara,N., Réjean L., Nizar B., Mathieu, O., 2008. Learning and novelty of innovation in established manufacturing SMEs. Technovation, 28(7): 450-463.

Attwood, R., 2010. We can work it out, Times Higher Education, 2nd September 2010.

Baldwin, J. R., Johnson, J., 1996. Business strategies in more- and less-innovative firms in Canada. Research Policy, 25(6): 785-804.

Batra G., Kaufmann, D., Andrew, H.W., 2003. Investment climate around the world: voices of the firms from the world business environment survey. World Bank Publications, Washington.

Batra, G., Tan, H. , 2002. Upgrading Work Force Skills to Create High-Performing Firms, in Nabi, I., Luthria, M. (Ed.), Building competitive firms: incentives and capabilities, World Bank Publications: Washington, pp.118-134.

Becker, G., 1964. Human capital: a theoretical and empirical analysis, with special reference to education. University of Chicago Press, Chicago.

Behrens, T. R., Gray, D.O., 2001. Unintended consequences of cooperative research: Impact of industry sponsorship on climate for academic freedom and other graduate student outcome. Research Policy, 30: 179-199.

Beltramo, J. P., Paul, J. J., Perret, C., 2001. The recruitment of researchers and the organization of scientific activity in industry. International Journal of Technology Management, 22(7/8): 811$\underline{834 .}$

Bodas Freitas, I.M., Bekkers, R., 2007. Exploring patterns of knowledge transfer from university to industry: do sectors matter? Proceedings of Triple Helix VI: 6th International Conference, Singapore, 16-18 May 2007.

Borrell-Damian, L., 2009. University industry partnerships for enhancing knowledge exchange. 
DOC-CAREERS Project, European University Association, Brussels.

Bosch, G. and Charest, J. (eds), 2009. Vocational training: international perspectives. Routledge, Abingdon.

Bowles, S., Gintis, H., Osborne, M., 2001. The determinants of earnings: a behavioural approach. Journal of Economic Literature, 39(4): 1137-1176.

Box, S., 2011. Background note for the OECD RIHR Workshop on Transferable Skills Training for Researchers: supporting career development and research. DSTI/STP/RIHR(2011)7. OECD, Paris.

Brown, P., Green, A. and Lauder, H., 2001. High skills: globalization, competitiveness, and skill formation. Oxford University Press, Oxford.

Burt, R. S., 1995. Structural holes: the social structure of competition. Harvard University Press.

Butcher, J., Jeffrey, P., 2007. A view from the coal face: UK research student perceptions of successful and unsuccessful collaborative projects. Research Policy, 36: 1239-1250.

Casper, S., Whitley, $R ., 2004$. Managing competences in entrepreneurial technology firms: a comparative institutional analysis of Germany, Sweden, and the UK. Research Policy, 33(1): 89106.

Chesbrough, H., 2003. Open innovation: the new imperative for creating and profiting from technology. Harvard Business School Press, Boston.

Construction Industry Training Board (CITB), 2002. Industrial Levy Order. UK Parliament: London.

Crouch, C., Finegold, D., Sako, M., 2001. Are Skills the Answer? Oxford University Press: Oxford.

Cruz-Castro, L., Sanz-Menedez, L., 2005. The employment of PhDs in firms: trajectories, mobility and innovation. Research Evaluation, 14 (1): 57-69.

Danish Agency for Science, Technology and Innovation, 2008. The Industrial PhD - An effective tool for innovation and knowledge sharing. Ministry of Science, Innovation and Higher Education, Copenhagen.

Danish Ministry of Business and Industry, 1996. Technological and organisational change Implications for labour demand, enterprise performance and industrial policy: the OECD jobs strategy. Ministry of Business and Industry, Copenhagen.

Dar, A. Canagarajah, S., Murphy P., 2003. Training levies: rationale and evidence from evaluations. World Bank, Washington.

Descy, P., Tessaring, M., 2005. The value of learning: evaluation and impact of education and training: third report on vocational training research in Europe: synthesis report. Office for Official Publications of the European Communities: Luxembourg.

Edquist, C., 2005. Systems of innovation: perspectives and challenges, in Fagerberg J., Mowery 
D.C., Nelson R.R. (Ed.), The Oxford Handbook of Innovation, Oxford University Press: Oxford, pp.181-208.

EIM/SEOR, 2005. Policy instruments to foster training of the employed: Vol. 1, 2. Summary Report, Rotterdam.

Enders, I., 2005. Border crossings: research training, knowledge dissemination and the transformation of academic work. Higher Education, 49 (1-2): 119-133.

Engestrom, Y., 2005. Developmental work research: expanding activity theory in practice. Lehmanns Media, Berlin.

European Commission, 2006. Mobility of researchers between academia and industry: 12 practical recommendations. Office for Official Publications of the European Communities, Luxembourg.

Freel, M., 2005. Patterns of innovation and skills in small firms. Technovation, 25 (2): 123-134.

Freeman, C. and Soete, L., 1997. The economics of industrial innovation. Routledge: London.

Gallie, D., 2009. Employment regimes and the quality of work. Oxford Scholarship Online, Oxford.

Gaughan, M., Robin, S., 2004. National science training policy and early scientific careers in France and the United States. Research Policy, 33: 569-581.

Gemme, B., Gringas, Y., 2004. Training a new breed of researchers, inside and outside universities. Working paper presented on colloquium on research and higher education policy, 1-3 December 2004. UNESCO, Paris.

Giraud, 0., 2002. Firms' further training practices and social exclusion: can industrial relations systems provide greater equality? Theoretical and empirical evidence from Germany and France, in Schomann, K., O'Connell, P.J. (Eds.), Employment Regimes and the Quality of Work.

Giret, J.-F., Recotillet, I., 2004. The impact of the CIFRE programme into early careers of PhD graduates in France. Presentation to the 16th Annual Conference of the European Association of Labor Economists, Lisbon, September 2004. Centre Associé Céreq pour les regions.

Gluck, M.E., Blumenthal, D., Soto, M.A., 1987. University-industry relationships in the life sciences: implications for students and post-doctoral fellows. Research Policy, 16: 327-336.

Greenhalgh, C., 2002. Does an employer training levy work? The incidence of and returns to adult vocational training in France and Britain. Fiscal Studies, 23(2): 223-263.

Griffith, R., Redding, S. and Van Reenen, J. , 2004. Mapping the Two Faces of R\&D: Productivity Growth in a Panel of OECD Industries, Review of Economics and Statistics. The Review of Economics and Statistics , 86(4): 883-895.

Grubb, W. N., 1996. Knowledge Intensive Business Services: Organizational Forms and National Institutions. Jossey-Bass Inc.: the University of Michigan. 
Hall, P.A., Soskice, D.W. , 2001. An introduction to varieties of capitalism, in Hancké, B. (Ed.), Knowledge Intensive Business Services: Organizational Forms and National Institutions, Oxford University Press, Oxford (pp.21-75).

Harman, K., 2002. The research training experiences of doctoral students linked to Australian cooperative research centres. Higher Education, 44: 469-492.

Harman, K., 2004. Producing 'industry-ready' doctorates: Australia cooperative research centre approaches to doctoral education'. Studies in Continuing Education, 26 (3): 387-404.

Human Resources Development Canada, 1997. Lessons learned: effectiveness of employmentrelated programs for youth. Evaluation and Data Development, Strategic Policy. Human Resources Development Canada, Ottawa.

Institute for the Future for Apollo Research Institute (2011). Future Work Skills 2020. Palo Alto, CA, USA.

Johanson, R., 2009. A review of national training funds. Korean Ministry of Labour and World Bank, Washington.

Keep, E., Mayhew, K., 2010. Moving beyond skills as a social and economic panacea. Work, Employment and Society, 24 (3): 565-577.

Kitagawa, F., 2011. Industrial doctorates - employer engagement in research and skills formation. Centre for Learning and Life Chances in Knowledge Economies and Societies.

Lam, A., 2001. Changing R\&D organisation and innovation: knowledge sourcing and competence building, in Verdier, E., Lam, A., Buechtemann, C. (Eds.), Higher Education and Industrial Innovation, LEST/CNRS, Paris (pp. 33-54).

Laplagne, P. and Bensted, L., (1999). The Role of training and innovation in workplace performance. Productivity Commission Staff Research PaperAusInfo, Canberra.

Leiponen, A., 1996. Education and innovative capabilities. International Institute for Applied Systems Analysis, Luxembourg: http://www.iiasa.ac.at/Admin/PUB/Documents/WP-96140.pdf.

Leitch Review of Skills , 2006. Prosperity for all in the global economy- world class skills. HM Treasury, London.

Lloyd-Ellis, H., Roberts, I., 2002. Twin engines of growth: skills and technology as equal partners in balanced growth. Journal of Economic Growth, 7(2): 87-115.

Lorenz, E., Lundvall, B A., 2006. How Europe's economies learn: coordinating competing models. Oxford University Press, Oxford.

Lundvall, B.A. , 1992. National systems of innovation: towards a theory of innovation and interactive learning. Pinter, London.

Malerba, F., 2004. Sectoral systems of innovation: basic concepts, in Malerba, F. (Ed.), Sectoral 
Systems of Innovation. Cambridge University Press, Cambridge (pp.9-41).

Mangematin, V., 2000. PhD job market: professional trajectories and incentives during the PhD. Research Policy, 29: 741-756.

Mangematin, V., Mandran, N., Crozet, A., 2000. Careers of PhDs in social science in France: the influence of how the research was done. European Journal of Education, 35(1): 111-124.

Mangematin, V., Robin, S., 2003. The two faces of PhD students: management of early careers of French PhDs in life sciences. Science and Public Policy, 30(6): 405-414.

Martinelli, D., 2001. Labor market entry and mobility of young French PhDs, in OECD, Innovative people: mobility of skilled personnel in national innovation systems. OECD, Paris.

Mason G., Bishop, K., 2010. Adult Training, Skills Updating and Recession in the UK: The Implications for Competitiveness and Social Inclusion. Centre for Learning and Life Chances in Knowledge Economies and Societies: LLAKES Research Paper, 10.

Mason, G., Beltramo, J.P., Paul, I.-I., 2004. External knowledge sourcing in different national settings: a comparison of electronics establishments in Britain and France. Research Policy, 33 (1): $53-72$.

Miller, R., 1996. Measuring what people know human capital accounting for the knowledge economy. OECD, Paris.

Miozzo, M. and Grimshaw, D., 2011. Capabilities of large services outsourcing firms: the "outsourcing plus staff transfer model" in EDS and IBM. Industrial and Corporate Change, 20(3): $\underline{909-940 .}$

Miozzo, M., Lehrer, M., DeFillippi, R., Grimshaw, D., Ordanini, A., 2010. Economies of scope through multi-unit skill systems: the organisation of large design firms. British Journal of Management, 23 (2): 145-164.

Moguerou, P., 2002. A comparison between the French and the US scientific labour market: academic vs. non-academic jobs. Working Paper, IREDU, Dijon.

National Audit Office, 2009. Train to gain: developing the skills of the workforce. National Audit Office, London.

Nilsson, A., 2010. Vocational education and training: an engine for economic growth. International Journal of Training and Development, 14(4): 251-272.

Nooteboom, B, Haverbekeb, W.V., Duystersc, G., Gilsingc, V., Oordc, A., 2007. Optimal cognitive distance and absorptive capacity. Research Policy, 36(7): 1016-1034.

OECD (2008a). Data collection on careers of doctorate holders: state of the art and prospects. Working Party of National Experts on Science and Technology Indicators, DSTI/EAS/STP/NESTI(2008)20.

OECD (2008b). Encouraging student interest in science and technology studies. OECD 
Publishing, Paris.

OECD, 1998. Human capital investment: an international comparison. OECD, Paris.

Patel, P., Pavitt, K., 1994. National innovation systems: why they are important, and how they might be measured and compared. Economics of Innovation and New Technology, 3(1): 77-95.

Perkmann, M., Walsh, K., 2007. University-industry relationships and open innovation: towards a research agenda. International Journal of Management Reviews, 9 (4): 259-280.

Ponomariov, B., Boardman, C., 2012. Organizational behavior and human resources management for public to private knowledge transfer: an analytic review of the literature. OECD Science, Technology and Industry Working Papers, 2012/01.

Porter, M. E., 1990. The competitive advantage of nations. MacMillan, London.

Powles, M., 1993. Postgraduates at the interface between higher education and industry. Research Working Paper 93.2. Centre for the Study of Higher Education, The University of Melbourne, Australia.

Rubenson, K., Schuetze, H.G., 1995. Learning at and through the workplace: a review of participation and adults learning theory, in Hirsch, D., Wagner, D.A. (Eds.), What Makes Workers Learn. Hampton Press, Cresskill, NJ (pp. 95-116).

Rodríguez-Pose, A., Vilalta-Bufi, M., 2005. Education, migration and job satisfaction: the regional returns of human capital in the EU. Journal of Economic Geography, 5 (5): 545-566.

Salminen-Karlsson, M., Wallgren, L., 2008. The interaction of academic and industrial supervisors in graduate research. An investigation of industrial research schools. Higher Education, 56: 77-93.

Slaughter, S., Campbell, T., Holleman, M., Morgan, E., 2002. The "traffic" in graduate students: graduate students as tokens of exchange between academe and industry. Science, Technology and Human Values, 27(2): 282-312.

Smits, W., 2008. The private benefits from vocational training: a new framework . CEDEFOP, Office for Official Publications of the European Communities, Luxembourg.

Snower, D.J., 1996. The low-skill, bad-job trap, in Booth, A.L., Snower, D.J. (Eds.), Acquiring skills: market failures, their symptoms and policy responses, Cambridge University Press, Cambridge (pp.111-124).

Steedman, H., Mason, G., Wagner, C., 1991. Intermediate skills in the workplace: deployment, standards and supply in Britain, France and Germany. National Institute Economic Review, 136 (1): $60-76$.

Stern, D., Bailey, T., Merritt, D., 1996. School-to-work policy insights from recent international developments. NCRVE, Berkeley.

Stone, I., 2010. Encouraging small firms to invest in training: learning from overseas. UKCES, Durham. 
Teece, D., and Pisano, G., 1998. The dynamic capabilities of firms: an introduction. Industrial and Corporate Change, 3(3): 537-556.

Teece, D., Pisano, G., Shuen, A., 1997. Dynamic capabilities and strategic management. Strategic Management Journal, 18 (7): 509-533.

Tether, B., Mina, A., Consoli, D., Gagliardi, D., 2005. A literature review on skills and innovation. how does successful innovation impact on the demand for skills and how do skills drive innovation?. CRIC Report for The Department of Trade and Industry, Manchester.

Thune, T., 2007. University-industry collaboration: the network embeddedness approach, Science and Public Policy. 34 (3): 158-168.

Thune, T., 2009. Doctoral students on the university-industry interface: a review of the literature, Higher Education, 58 (5): 637-651.

Thune, T., 2010. The training of "triple helix workers"? doctoral students in universityindustry-government collaborations. Minerva, 48 (4): 463-483.

Trampusch, C., Eichenberger, P., de Roo, M., Bartlett Rissi, R., Bieri, I., Schmid, L., Steinlin, S. (eds.), 2010. Continuing vocational training in the Netherlands. REBECA (Research on Social Benefits in Collective Agreements). SNF-Project No. 100012-119898. University of Berne.

Wallgren, L., Dahlgren, L.O., 2007. Industrial doctoral students as brokers between industry and academia. Industry and Higher Education, 21: 195-210.

Wallgren, L., Dahlgren, L.O., 2005. Doctoral education as social practice for knowledge development: conditions and demands encountered by industry PhD students. Industry and Higher Education, 19:433-443.

Warhurst, C., Grugulis, I., Keep, E., 2004. The Skills that Matter. Palgrave Macmillan: New York.

Whitley, R., 2006. Project-based firms: new organizational form or variations on a theme? Industrial and Corporate Change, 15(1): 77-99.

Zucker, L., Darby, M., Torero, M., 2002. Labour mobility from academe to commerce. Journal of Labour Economics, 20 (3): 629-660. 


\section{Manchester Institute of Innovation Research}

The Manchester Institute of Innovation Research (MloIR) is the research centre of excellence in the Manchester Business School (MBS) and The University of Manchester in the field of innovation and science studies. With more than 50 full members and a range of associated academics from across the University, MloIR is Europe's largest and one of the World's leading research centres in this field.

The Institute's key strengths lie in the linkage and cross-fertilisation of economics, management and policy around innovation and science. Building on forty years of tradition in innovation and science studies, the Institute's philosophy is to combine academic rigour with concrete practical relevance for policy and management. This includes broad engagement with and research for policy makers and societal and industrial stakeholders in the Manchester City Region, across the UK and internationally. MloIR is also firmly committed to a range of teaching activities within and beyond MBS and integrates a strong and successful PhD programme into its research activities. The Institute has a visitor programme for academics and management and policy practitioners and provides a range of popular and high level executive education courses on evaluation, foresight and S\&T Policy. 